\title{
The Impact of Housing and Basic Service Delivery on Low-Income Communities in South Africa: The Case of the northern Free State Region
}

\author{
Dr Daniel Francois Meyer \\ Faculty of Economic Sciences and Information Technology School of Economics \\ North-West University (Vaal Triangle Campus) South Africa \\ Email: daniel.meyer@nwu.ac.za
}

\section{Doi:10.5901/mjss.2014.v5n13p11}

\begin{abstract}
This article investigates the impact of the provision of housing and basic services on poor communities in the northern Free State (NFS) region of South Africa. Service delivery and housing backlogs in poor communities have led to an increase in violent protest marches throughout the country. Poor communities seem frustrated with the rate of service delivery since the election of the first democratic government in 1994. A community household survey, which included 2900 households, was conducted in 2013 in the NFS region and included twelve poor communities. The regional result was compared with four selected poor communities in the region, namely Moakeng (Moghaka Local Municipality), Qalabotjha (Mafube Local Municipality), Tumahole (Ngwathe Local Municipality) and Zamdela (Metsimaholo Local Municipality). The impact of delivery of basic services and housing were analysed regarding poverty levels, as well as the relationship between the concepts of poverty and service delivery. Results of the survey indicate that 75.9 percent of the households reside in formal subsidised houses with high levels of ownership but a relatively low average monthly household income of only R1 458 (\$140/month) relating to high levels of poverty. Only 35.6 percent of all households surveyed are of the subjective opinion that local government delivers quality services. More detailed results per specific area are analysed and discussed in the article. The results could play an important role in development policy formulation and policy adjustment. The results should also be taken into account in the formulation of local economic development (LED) plans for the areas under investigation with a focus on the benefits of housing delivery and associated basic services. Improved service delivery must be promoted by means of improved coordination between all spheres of government.
\end{abstract}

Keywords: service delivery, housing provision, local government, poverty, northern Free State region

\section{Introduction}

After twenty years of democratic government, South Africa still faces endemic levels of unemployment, poverty and inequality as identified in the National Development Plan (NDP) (Republic of South Africa, 2011). "Endemic and wide spread poverty continue to disfigure the face of our country. It will always be impossible for us to say that we have fully restored the dignity of all our people as long as this situation persists" (Mbeki, 2006). More than 50 percent of South African households live in poverty, and in most cases, these households lack the basic services required to live a quality life. According to Statistics South Africa (2014), the poverty level in 2009 was 56.8 percent, which has decreased from 57.2 percent in 2006. Housing and basic services play a vital role in meeting the basic needs of poor communities. Housing provides the security required for a household to function and is a requirement for alleviation of poverty (Mamba, 2006).

In 2005, Clark and Qizilbash did a study in poor areas of South Africa and respondents were asked what basic needs are most required to survive by poor households. As a result of the survey, basic needs were ranked. Subsequently, housing ranked the highest priority, followed by food, water, jobs, income, clothes, education, health care, electricity, safety, transport, family, sanitation, and infrastructure. As could be expected, luxury activities such as sports, recreation and leisure activities were not ranked as high-level priorities for the poor (Clark \& Qizilbash, 2005).

Huge backlogs related to housing and basic services still exist in South Africa due to mainly the apartheid history. In 1994, with the establishment of democracy in South Africa, the Reconstruction and Development Programme (RDP) was released as a guiding policy document. Already then, the provision of basic infrastructure was identified as a key priority for the reconstruction of the county and improvement of quality of life (ANC, 1994). Post-apartheid development policy in South Africa has focused on the effective and efficient delivery of basic services, especially to those that historically have been deprived of services such as water, sanitation, housing, electricity and health services (CSIR, 2012). Housing is seen as one of the main basic needs for survival of the poor. Service delivery since 1994 has been impressive, taking into account the massive backlogs, with the implemention of a number of pro-poor policies such as 
housing subsidies, and free basic water and electricity.

However, urbanisation has left large urban communities without basic services (Alexander, 2010). President Zuma's government is fully aware of the importance of providing and resolving these backlogs. In his State of the Nation Address (SONA) in 2011, he stated that although many poor people have received services, many are still waiting for housing and basic services (Zuma, 2011). Government has to create an enabling environment for all, including for the poor, to allow access to opportunities through the provision of housing and basic services. Access to such services is still lacking, especially in rural areas. The South African housing policy states that all citizens should have access to basic services, irrespective of their locality (Mamba, 2006).

Due to the unresolved service delivery backlogs, the number of protest actions has increased drastically over the last few years in South Africa. From mid 2013 up to end of April 2014, the country had an average of approximately four anti-government protests a day, and most protests are violent in nature. The country seems to be witnessing the development of a protest movement of poor communities showing their anger and frustration at the service delivery performance of government. Since 1994, living standards of all communities have improved through massive service delivery projects, but according to the South African Institute of Race Relations (SAIRR), this has led to a theory of rising expectations. The service delivery improvements have led to increased living standards but unemployment has increased. The poor communities are still poor and caught up in a vicious cycle of poverty. A mindshift with applicable policy amendments is needed. The unemployed are now looking at government to provide jobs, which is not a pure government function (SAIRR, 2014). The eradication of poverty is also one of the key priorities of the South African government. Various government policies have been introduced to improve the welfare of poor households, including access to housing and basic services (SALGA, 2010).

This article aims to investigate the impact of the provision of housing and basic services on poverty in a typical, poor South African township. The geographical focus of the article is on the poor communities in the northern Free State (NFS) region of South Africa. Approximately 2900 poor households were interviewed as part of the quantitative section of the research.

\section{Conceptual Background}

The provision of housing for low-income communities has a vital role to play in allowing households to function, and is essential for human development. Housing provides both environmental services such as clean water and energy, and locational services with access to opportunities and social facilities (Marais, 1998; Stewart, 1997). Housing with basic services improve the physical welfare of the poor, assist with entrepreneurial activities, builds an asset base, allows privacy, strengthens social relations, status improvement, and control over the local environment (Pynoos, 1973). Housing with basic services also has an impact on the quality of parenting and social factors. Homelessness can lead to problems such as illness, neglect, injuries, family separation, and impaired academic functioning (Crowley, 2003).

According to Harber (2009), service delivery as a concept is not neutral. Service delivery includes a host of assumptions, policies and promises. Governments make election promises on service delivery, which in most cases, they cannot achieve. Government needs to deliver, and communities need to receive, services. The World Bank (2003) recognises there is no template for successful service delivery, but places the overall responsibility of making services work on the state, especially for poor communities.

"Poverty reduction is not only about meeting our basic needs, it's about participation, influence and power" (Sundqvist, 2009). Poverty is defined as a failure to achieve certain minimum basic needs or capacities (Sen, 1999). Shaffer (2008) defines poverty as the deprivation of material requirements for the minimum acceptable fulfilment of basic needs. The existence of poverty is a multi-dimensional problem, which includes the meeting of basic needs (SPII, 2007).

Poverty entails more than a lack of income, as it exists when an individual or household has inadequate access to income, jobs, infrastructure and basic services. Poverty is caused by a combination of variables including social, economic, spatial, environmental and political factors (Muller, 2003). Recent poverty alleviation strategies have focused on the provision of basic needs rather than merely attempting to raise incomes (Tomlinson, 2007). Poverty could be measured in many ways, and individuals may base their self-perceived subjective poverty on a number of factors, which may include lack of access to basic services, lack of access to land and housing, poor health facilities, lack of income and employment (Statistics South Africa, 2012a).

Housing delivery and transfer of ownership to the poor is seen by De Soto (2000) as a strategy to lift people out of poverty and giving them access to assets. Allocation of assets leads to the opportunity of entrepreneurship and the creation of wealth. Table 1 is a summary of important developmental and service delivery data for South Africa, the Free State province and the NFS region, which forms part of the Free State. Low levels of human development (HDI) and 
literacy still exist, although these have improved slightly over the last 20 years of democracy. The levels of inequality are still relatively high if compared to most African and developing countries. The level of service delivery is relatively high and in general, the levels of service delivery are better in the NFS region than in the rest of the province and South Africa.

Table 1: Key developmental and service delivery data

\begin{tabular}{|l|c|c|c|}
\hline \multicolumn{1}{|c|}{ Indicator } & South Africa & Free State Province & Northern Free State (NFS) \\
\hline \multicolumn{1}{|c|}{ HDI } & 0.59 & 0.55 & 0.58 \\
\hline Gini-coefficient & 0.63 & 0.64 & 0.63 \\
\hline Literacy levels & 73.5 & 72.2 & 74.4 \\
\hline Percentage of households connected to sewer systems & 57.0 & 64.9 & 81.7 \\
\hline $\begin{array}{l}\text { Percentage of households receiving weekly refuse } \\
\text { removal services }\end{array}$ & $\mathrm{Na}$ & 71.0 & 56.7 \\
\hline Percentage of households connected to piped water & 73.4 & 44.8 & 89.8 \\
\hline Percentage of households connected electricity & 84.7 & 89.9 & 8 \\
\hline
\end{tabular}

Source: Global Insight (2012) and StatsSA (2012b)

In South Africa, a total housing backlog of 2.1 million units exists, affecting approximately 12.5 million people. The Department of Human Settlements is responsible for housing provision for the poor. People with an income of less than R3 500 (\$333.00) per month can qualify for housing assistance by means of a housing subsidy. The NFS regional housing backlog was 40000 units in 2000 and reduced to 34000 in 2010. A total of 83.1 percent of all housing units in the study region consist of formal housing (Republic of South Africa, 2014; Housing Development Agency, 2012).

\section{Research Methodology}

\subsection{Research approach}

The approach followed was first, a literature review, which served as the theoretical basis of the research and secondly, a quantitative household survey in poor communities, as part of the empirical component of the research. Findings and recommendations were deducted from the literature review and the empirical phases of the research.

\subsection{Sample}

A quantitative research approach was used to collect data by means of a community household survey in the NFS region during January 2013. The region is located in the Free State province and directly south of the Gauteng province. The Vaal river forms the northern boundary of the region. The region is also known as the Fezile Dabi District Municipal region and includes the local municipalities of Mafube, Metsimaholo, Moghaka and Ngwathe, as well as the regional authority known as the Fezile Dabi District Municipality. The region could be described as a rural region with major rural towns such as Sasolburg/Zamdela, Parys/Thumahole, Kroonstad/Moakeng and Frankfort/Namahadi. The household survey focused on twelve poor communities in the NFS region and approximately 2900 households were included.

For the purposes of this study, four of the twelve poor communities were compared in terms of housing delivery and basic services. The four communities Moakeng (located adjacent to Kroonstad), Qalabotjha (located next to Villiers), Tumahole (located near Parys) and Zamdela (located next to Sasolburg). As a rule, a 10 percent sample was selected per poor community. Households in the study area were selected randomly from the various areas. In the analysis of the survey, households were compared in terms of level of poverty, income, housing delivery and subjective perceptions regarding basic service delivery. The results for the total region, as well as for the households in the four selected communities are presented.

\subsection{Instrument and procedures}

Primary data were collected by means of a questionnaire, which was developed based on a comprehensive literature review. The questionnaire comprised various sections, which include demographics, income and expenditure, perceptions of government service delivery, life satisfaction, skills levels and employment aspects of poor people. 
Specific questions regarding this article include the type of housing, housing ownership, housing subsidy received and subjective perceptions regarding basic services as provided by the specific municipality.

\subsection{Ethical considerations}

Prior to the administration of the questionnaire, the specific ward councillors and local community leaders were approached with a request to conduct the study in the area. After permission was granted, potential participants were approached. In addition to a verbal explanation of the purpose of the study, they were also provided with a cover letter explaining the purpose of the study. Once informed consent was obtained from the participants, the procedure to complete the questionnaire was outlined. Participants were assured of confidentiality and anonymity. They were also informed that participation was voluntary and they could withdraw at any stage from the study without any repercussions.

\subsection{Data analysis}

The survey data were captured and analysed using the Statistical Package for the Social Sciences (SPSS), version 22 software package. Descriptive statistics were used to report on the data. Pearson's chi-square test was applied in order to determine the existence of significant differences between the two groups in the study area (households below the poverty line and households above the poverty line).

\section{Results}

\subsection{Poverty status}

The poverty status of households was calculated using the international US $\$ 2$ per day, per person, poverty line. To establish a poverty line for individuals in the household, the $\$ 2$ was multiplied by 30 (average number of days in a month) and then by the exchange rate of R11.00 to $\$ 1$. The monthly poverty line for an individual was calculated and set at R660 (\$62.90) per month. Of all the households in the NFS region, 74.2 percent are classified as below the poverty line, while 25.8 percent of households are classified as above the poverty line. The average income per household was established at R1 458 (\$140) per month, which confirms the relative low-income levels in the study area. It should be mentioned that even the households above the poverty line are just marginally above the poverty line and are mostly poor. Therefore, the total study area is regarded as a poor area. Table 2 provides a summary of the poverty lines in the study area. Poverty levels are high in the study area within the communities as surveyed. The Qalabothla community had the highest poverty levels with 81.3 percent of households below the poverty line, while Zamdela had the lowest poverty level of 65 percent of all households below the poverty line.

Table 2: Poverty lines in the study area

\begin{tabular}{|l|c|c|}
\hline \multicolumn{1}{|c|}{ Areas } & $\begin{array}{c}\text { Percentage of households below } \\
\text { poverty line }\end{array}$ & $\begin{array}{c}\text { Percentage of households above poverty } \\
\text { line }\end{array}$ \\
\hline All poor communities in study region & 74.2 & 25.8 \\
\hline Qalabothla & 81.3 & 18.7 \\
\hline Moakeng & 79.3 & 20.7 \\
\hline Zamdela & 65.0 & 35.0 \\
\hline Tumahole & 79.1 & 20.9 \\
\hline
\end{tabular}

Table 3 indicates household size and income levels per household in the study area. The average household size in the study area is 3.8 people per household. Household size and poverty levels are related, and this relationship is evident from tables 2 and 3. Larger households relates to higher levels of poverty. For example, the Qalabothla community had the largest household sizes on average of 4.1 , and also the highest levels of poverty in the study area. Qalabothla had the lowest average income per person at R316 (\$30.10) per month while Zamdela had the highest income levels at R484 (\$46.10) per person per month. 
Table 3: Household size and income per household

\begin{tabular}{|l|c|c|c|c|}
\hline \multicolumn{1}{|c|}{ Areas } & $\begin{array}{c}\text { Number of households } \\
\text { included in survey }(\mathrm{n})\end{array}$ & $\begin{array}{c}\text { Household } \\
\text { size }\end{array}$ & $\begin{array}{c}\text { Average household income (\$ } \\
\text { value in brackets) }\end{array}$ & $\begin{array}{c}\text { Average income per person }(\$ \\
\text { value in brackets) }\end{array}$ \\
\hline $\begin{array}{l}\text { All poor communities in } \\
\text { study region }\end{array}$ & 2921 & 3.8 & $\mathrm{R} 1458.00(\$ 140.20)$ & $\mathrm{R} 383.68(\$ 34.90)$ \\
\hline Qalabothla & 166 & 4.1 & $\mathrm{R} 1297.00(\$ 124.70)$ & $\mathrm{R} 316.34(\$ 30.38)$ \\
\hline Moakeng & 363 & 3.6 & $\mathrm{R} 1170.00(\$ 112.50)$ & $\mathrm{R} 325.00(\$ 31.25)$ \\
\hline Zamdela & 980 & 3.5 & $\mathrm{R} 1696.00(\$ 163.10)$ & $\mathrm{R} 484.57(\$ 46.54)$ \\
\hline Tumahole & 393 & 3.9 & $\mathrm{R} 1496.00(\$ 143.85)$ & $\mathrm{R} 383.59(\$ 36.83)$ \\
\hline
\end{tabular}

\subsection{Housing provision}

According to StatsSA (2012b), urban formal housing comprised of 28.2 percent for the total NFS region, compared to 68.3 percent for urban informal housing. The study area, comprising of only poor communities, had higher levels of formal housing due to the housing subsidy scheme for the poor. Table 4 indicates housing types and ownership per area. Overall 75.9 percent of households reside in formal dwellings and only 19.0 percent in informal dwellings (shacks) in the study area. Qalabothla had the highest percentage of people living in formal housing units, mostly due to the housing subsidy system for poor households, as it is the poorest community in the area.

Table 4: Housing type and ownership in the study area

\begin{tabular}{|l|c|c|c|c|c|c|}
\hline \multicolumn{1}{|c|}{ Areas } & \multicolumn{3}{c|}{ Housing type } & \multicolumn{3}{c|}{ Housing ownership } \\
\hline & Formal house & Shack & Other & Ownership & Rental & Other \\
\hline \multicolumn{1}{|c|}{ All poor communities in study region } & 75.9 & 19.0 & 5.1 & 76.0 & 17.2 & 6.8 \\
\hline Qalabothla & 87.3 & 10.9 & 1.8 & 88.0 & 5.3 & 6.7 \\
\hline Moakeng & 75.5 & 16.2 & 8.4 & 61.0 & 16.8 & 22.2 \\
\hline Zamdela & 76.4 & 20.6 & 2.2 & 77.0 & 18.8 & 4.2 \\
\hline Tumahole & 76.9 & 15.4 & 4.4 & 78.0 & 17.6 & 4.4 \\
\hline
\end{tabular}

Table 5 indicates the relationship between housing type and poverty lines. A total of 73.1 percent of households below the poverty line reside in formal housing, while 83.9 percent of households above the poverty line live in formal housing. A total of 20.9 percent of households living below the poverty line reside in informal structures, while only 13.6 percent of households above the poverty line live in shacks. A significant statistical difference exists between the households living below and above the poverty line with regards to the type of housing with a chi-square of 37.72 and a p value of 0.000 . The Qalabothla area is the only area that did not show evidence of the difference between the two groups.

Table 5: Housing type and poverty lines

\begin{tabular}{|l|c|c|c|c|}
\hline \multicolumn{1}{|c|}{ Areas } & $\begin{array}{c}\text { Households below poverty line with } \\
\text { formal housing (\%) }\end{array}$ & $\begin{array}{c}\text { Households above poverty line with } \\
\text { formal housing (\%) }\end{array}$ & $\begin{array}{c}\text { chi- } \\
\text { square }\end{array}$ & $\begin{array}{c}\text { - } \\
\text { value }\end{array}$ \\
\hline $\begin{array}{c}\text { All poor communities in } \\
\text { study region }\end{array}$ & 73.1 & 83.9 & 37.72 & 0.000 \\
\hline Qalabothla & 86.6 & 90.3 & 0.788 & 0.674 \\
\hline Moakeng & 72.5 & 86.7 & 7.178 & 0.028 \\
\hline Zamdela & 73.8 & 81.3 & 7.868 & 0.097 \\
\hline Tumahole & 73.7 & 88.9 & 9.710 & 0.084 \\
\hline
\end{tabular}

Table 6 indicates the relationship between property ownership and poverty lines. A total of 83.3 percent of households below the poverty line have ownership, while 89.7 percent of households above the poverty line have property ownership. A total of 16.6 percent of households living below the poverty line have no property ownership, while only 10.1 percent of households above the poverty line have no property ownership. A significant statistical difference exists between the households living below and above the poverty line with regards to property ownership with a chi-square of 59.58 and a $p$ value of 0.000 . The Tumahole area is the only area where no significant difference was recorded between the two groups. 
Table 6: Property ownership and poverty lines

\begin{tabular}{|c|c|c|c|c|}
\hline Areas & $\begin{array}{l}\text { Households below the poverty line with } \\
\text { property ownership (\%) }\end{array}$ & $\begin{array}{l}\text { Households above the poverty line with } \\
\text { property ownership (\%) }\end{array}$ & $\begin{array}{l}\text { chi- } \\
\text { square }\end{array}$ & $\begin{array}{c}\mathrm{p}- \\
\text { value }\end{array}$ \\
\hline $\begin{array}{c}\text { All poor communities in } \\
\text { study region }\end{array}$ & 83.3 & 89.7 & 59.58 & 0.000 \\
\hline Qalabothla & 90.2 & 93.5 & 7.29 & 0.063 \\
\hline Moakeng & 52.8 & 83.9 & 24.51 & 0.000 \\
\hline Zamdela & 54.3 & 72.7 & 33.139 & 0.000 \\
\hline Tumahole & 34.4 & 38.8 & 1.666 & 0.948 \\
\hline
\end{tabular}

Table 7 indicates the relationship between housing subsidy received and poverty lines. A total of 38.7 percent of households below the poverty line received housing subsidies, while 46.5 percent of households above the poverty line received housing subsidies. A total of 61.3 percent of households living below the poverty line did not receive housing subsidies, while only 53.5 percent of households above the poverty line did not receive housing subsidies. A significant statistical difference exists between the households living below and above the poverty line with regards to housing subsidy received with a chi-square of 29.08 and a p value of 0.000 . For the study area, significant differences exist between the two groups, but for individual areas the relationship between housing subsidy and the impact on poverty levels are not clear.

Table 7: Housing subsidy received and poverty lines

\begin{tabular}{|l|c|c|c|c|}
\hline \multicolumn{1}{|c|}{ Areas } & $\begin{array}{c}\text { Households below the poverty line with } \\
\text { housing subsidy (\%) }\end{array}$ & $\begin{array}{c}\text { Households above poverty line with } \\
\text { housing subsidy (\%) }\end{array}$ & $\begin{array}{c}\text { chi- } \\
\text { square }\end{array}$ & $\begin{array}{c}\mathrm{p}- \\
\text { value }\end{array}$ \\
\hline $\begin{array}{c}\text { All poor communities in } \\
\text { study region }\end{array}$ & 38.7 & 46.5 & 29.08 & 0.000 \\
\hline Qalabothla & 35.2 & 29.0 & 1.58 & 0.664 \\
\hline Moakeng & 9.9 & 13.9 & 1.779 & 0.619 \\
\hline Zamdela & 34.7 & 53.0 & 40.302 & 0.000 \\
\hline Tumahole & 46.2 & 29.2 & 18.196 & 0.003 \\
\hline
\end{tabular}

\subsection{Service delivery}

This section of the research analyses the subjective perceptions of the poor communities in the study area, with regard to service delivery by the various municipalities in the region. Table 8 provides information on the subjective perceptions of poor households in the study area on service delivery. Generally, households are of the opinion that poor service delivery exists in the study area. A total of 51.0 percent of households are of the opinion that poor services are provided while only 35.6 percent feel that service delivery is good. The communities of Zamdela and Tumahole are most dissatisfied with service delivery in the area. These two communities are characterised by ongoing violent protest action focused on poor service delivery in the area by the municipality.

Table 8: Subjective perceptions of service delivery

\begin{tabular}{|l|c|c|c|}
\hline \multicolumn{1}{|c|}{ Areas } & $\begin{array}{c}\text { Subjective perception of households: } \\
\text { Local government is providing good } \\
\text { services delivery (\%) }\end{array}$ & $\begin{array}{c}\text { Subjective perception of households: Local } \\
\text { government is providing poor services delivery } \\
(\%)\end{array}$ & $\begin{array}{c}\text { Uncertain } \\
(\%)\end{array}$ \\
\hline $\begin{array}{c}\text { All poor communities in } \\
\text { study region }\end{array}$ & 35.6 & 51.0 & 11.8 \\
\hline Qalabothla & 36.9 & 38.3 & 24.0 \\
\hline Moakeng & 48.4 & 38.9 & 12.7 \\
\hline Zamdela & 22.5 & 69.4 & 7.0 \\
\hline Tumahole & 40.3 & 50.5 & 8.0 \\
\hline
\end{tabular}

Table 9 provides an indication of which basic services are most lacking in the study area. The overall perception of poor households is that housing is most lacking, followed by water, electricity and medical services. The individual communities have similar perception of which services are most lacking in their areas. Housing has been prioritised as 
the highest rated basic need in the study area.

Table 9: Basic services most lacking in the study area

\begin{tabular}{|l|c|c|c|c|}
\hline \multicolumn{1}{|c|}{ Areas } & $\begin{array}{c}\text { Basic service lacking most } \\
\text { (subjective household } \\
\text { perception) (\%) }\end{array}$ & $\begin{array}{c}\text { Basic service lacking } \\
\text { second most (subjective } \\
\text { household perception) (\%) }\end{array}$ & $\begin{array}{c}\text { Basic service lacking third } \\
\text { most (subjective household } \\
\text { perception) (\%) }\end{array}$ & $\begin{array}{c}\text { Basic service lacking } \\
\text { fourth most (subjective } \\
\text { household perception) (\%) }\end{array}$ \\
\hline $\begin{array}{c}\text { All poor } \\
\text { communities in } \\
\text { study region }\end{array}$ & Housing (27.7\%) & Water (20.1\%) & Electricity (18.3\%) & Medical access (10.0\%) \\
\hline Qalabothla & Water (37.7\%) & Medical access (17.4\%) & Housing (14.5\%) & $\begin{array}{c}\text { Parks and recreation } \\
\text { facilities (12.4\%) }\end{array}$ \\
\hline Moakeng & Housing (62.0\%) & Water (11.0\%) & Electricity (9.3\%) & Education (8.35) \\
\hline Zamdela & Electricity (33.2\%) & Medical access (14.7\%) & Sewer (13.9\%) & Housing (11.8\%) \\
\hline Tumahole & Water (45.2\%) & Housing (20.1\%) & Electricity (14.1\%) & Medical access (8.5\%) \\
\hline
\end{tabular}

Table 10 indicates the relationship between perceptions on service delivery and poverty lines. A total of 35.3 percent of households below the poverty line are satisfied with service delivery, while 37.1 percent of households above the poverty line are satisfied with service delivery. From the above it is clear that no significant statistical difference exists between the households living below and above the poverty line with regards to perceptions on service delivery, with a chi-square of 5.938 and a $p$ value of 0.430 .

Table 10: Perceptions of poor and non-poor households in relation to service delivery

\begin{tabular}{|l|c|c|c|c|}
\hline \multicolumn{1}{|c|}{ Areas } & $\begin{array}{c}\text { Service delivery perceptions of households } \\
\text { below the poverty line indicating good service } \\
\text { delivery (\%) }\end{array}$ & $\begin{array}{c}\text { Service delivery perceptions of households } \\
\text { above the poverty line indicating good service } \\
\text { delivery (\%) }\end{array}$ & $\begin{array}{c}\text { chi- } \\
\text { square }\end{array}$ & $\begin{array}{c}p- \\
\text { value }\end{array}$ \\
\hline $\begin{array}{l}\text { All poor communities } \\
\text { in study region }\end{array}$ & 35.3 & 37.1 & 5.938 & 0.430 \\
\hline Qalabothla & 34.6 & 50.0 & 9.580 & 0.048 \\
\hline Moakeng & 46.6 & 55.2 & 1.938 & 0.585 \\
\hline Zamdela & 24.2 & 21.6 & 4.071 & 0.667 \\
\hline Tumahole & 39.9 & 43.6 & 1.866 & 0.760 \\
\hline
\end{tabular}

Table 11 gives an indication of the perceptions of households in relation to which component of service delivery the study are lacks the most. Significant differences exist between the perceptions of households below and above the poverty line, with a chi-square of 51.530 and $p$-value of 0.000 . For households below the poverty line, housing is the service most lacking, followed by water, electricity and sewerage. For households above the poverty line, electricity is most lacking followed by housing, water and medical access.

Table 11: Perceptions of service delivery components most lacking in relation to poverty

\begin{tabular}{|l|c|c|c|c|}
\hline \multicolumn{1}{|c|}{ Areas } & $\begin{array}{c}\text { Service delivery component most lacking for } \\
\text { households below the poverty line (listed in } \\
\text { order of priority, top four services only) }\end{array}$ & $\begin{array}{c}\text { Service delivery component most lacking } \\
\text { for households above the poverty line (list in } \\
\text { order of priority, top four services only) }\end{array}$ & $\begin{array}{c}\text { chi- } \\
\text { square }\end{array}$ & $\begin{array}{c}\text { p- } \\
\text { value }\end{array}$ \\
\hline $\begin{array}{c}\text { All poor } \\
\text { communities in } \\
\text { study region }\end{array}$ & Housing, water, electricity, sewer. & $\begin{array}{c}\text { Electricity, housing, water and medical } \\
\text { access. }\end{array}$ & 51.530 & 0.000 \\
\hline $\begin{array}{l}\text { Qalabothla } \\
\text { Moakeng }\end{array}$ & Water, medical access, housing and parks. & Water, housing, medical access and parks. & 14.470 & 0.025 \\
\hline Zamdela & Electricity, medical access, housing and sewer. & Electricity, sewer, medical access and \\
parks. & 21.35 & 0.002 \\
\hline Tumahole & Water, housing, electricity and sewer. & $\begin{array}{c}\text { Water, housing, electricity and medical } \\
\text { access }\end{array}$ & 13.092 & 0.000 \\
\hline
\end{tabular}




\section{Discussion}

In theory, the provisions of housing and basic services for the poor assist with poverty alleviation and wealth creation. In South Africa, a massive service delivery programme has been implemented. Although significant backlogs still exist, the programme, in coordination with a social-welfare programme, has resulted in improved quality of life for the poor. These safety net programmes were necessary due to the legacy of apartheid, but government has not placed enough focus on job creation and has left poor communities in a vicious cycle of poverty. Housing and basic services are key basic needs components, but does the provision thereof impact positively on poverty reduction?

In the study area, the more rural communities are poorer than the more urban communities, which are located closer to the economic hinterland of the Gauteng province. For example, the Qalabothla community is the poorest of the four communities included in this article. This community is located more than two hour's driving time from the centre of Gauteng province. In comparison, the Zamdela community has the highest average income per household and is located less than one hour's drive from central Gauteng.

Results of the survey indicate that the majority of households have received housing and basic services in the study area. More households living above the poverty line than households living below the poverty line in the study area reside in formal subsidised housing. This indicates that housing delivery can assist in poverty alleviation and be part of a local economic development strategy. Housing allows for household security and ownership of physical assets. For poor households, the allocation of assets leads to the creation of wealth and security. The results show that provision of housing for the poor, through subsidies, is necessary and has an impact on poverty reduction.

Although the study area has been part of a large scale basic services roll-out programme, the majority of the households are of the opinion that service delivery is of poor quality. Only 35 percent of all households interviewed are of the opinion that good quality basic services are provided. Consistent with the results of the study by Clark and Qizilbash (2005), which indicated that housing is the main basic need for the poor, housing is the basic need and service provided by government that is most lacking in the study area. Other essential basic services that are also lacking are water, electricity and medical services.

No significant differences were found in the survey between households living below the poverty line and households living above the poverty line regarding receptions of service delivery by local municipalities in the area. The two groups of households have however, different perceptions regarding which basic services lack most in their specific communities. Households living below the poverty line focus more on basic essential services, while households living above the poverty line focus more on higher level services such as electricity and medical services.

\section{Recommendations and Conclusions}

This study has found that housing provision and service delivery can have a positive impact on poverty levels and should be used as a strategy as part of a local economic development (LED) plan as was also confirmed by De Soto (2000). Benefits of housing delivery to the poor are multi-dimensional. It allows beneficiaries access to assets and wealth creation, can create jobs through construction and maintenance, allows for skills development, provides decent shelter as part of a basic needs approach, it is usually accompanied by infrastructure, facilities and basic services, and allows poor people dignity. The provision of housing can serve as a safety net and the improvement of the quality of life for poor communities. Good service delivery, including housing and basic services, remains central to the actualisation of a meaningful life and a quality of life for residents of poor communities. Improved services are linked to an increase in the dignity of the poor (Nleya, 2011).

Policy reforms are required with a paradigm shift from the delivery of large scale free basic services to job creation and deregulation of the local economy (SAIRR, 2014). The pace of basic service delivery and momentum must be maintained, but needs to be accompanied with rapid economic growth at no less than 5 percent per annum (compared to the current growth rate of 2.0\%). Government's economic development policies contradict the overall goal of increased economic growth and stand in the way of higher growth rates. Some policies are hostile to investment and entrepreneurship such as the Employment Equity Act, the Labour Relations Act and the Black Economic Empowerment (BEE) regulations. Reforms are needed to focus on deregulating the economy to remove the constraints on development and investment (SAIRR, 2014).

According to Fjeldstad et al. (2005), government, and especially local government, has specific problems regarding service delivery. Improvements are required concerning the following aspects at the local government/municipal sphere. Capacity needs to be increased regarding strategic planning focused on LED, housing and service delivery. The different powers and functions allocated to the different spheres of government need to be re-evaluated. Local government has 
been struggling to deliver basic services over the last decade. For example, LED is a local function, but are regarded as a luxury by most municipalities and are therefore not sufficiently budgeted and planned for. Housing delivery is on the other hand a provincial function, but most people blames municipalities for lack of housing provision. Improved public participation will assist in improved communication and will allow the public to understand better the process and functions. Closer cooperation is required between municipalities and provincial authorities. Municipalities should use service delivery and infrastructure development as a poverty reduction strategy and use service delivery as a safety net for the very poor. Local government, as the sphere of government closest to the people, has to play a significant role in the needs assessment of local communities, and the planning, provision and maintenance of basic services. It is also local government's duty to identify basic need gaps in poor areas, and to provide for such needs.

According to Gumbo (2014), the housing delivery process for low-income communities needs re-evaluation due to the slow and complicated process. It should be changed from the traditional process of from planning, to service provision, to construction, to occupation, to the proposed process of starting with planning, then allowing occupation on an informal basis, then construction of formal housing and lastly, the provision of basic services.

Municipalities should improve on the process of integrated planning by ensuring that the poor section of the community has access to services and economic opportunities by means of effective spatial planning actions.

In conclusion, the aim of the article was to investigate the impact of housing provision and service delivery on poverty. It is interesting to note that both housing and basic service delivery improves the level of poverty, but it also improves the quality of life of poor communities. However, housing and basic service delivery without job creation will not lead to a substantial reduction of poverty.

\section{References}

African National Congress (ANC). (1994). The reconstruction and development programme. Johannesburg. Umnyanyano Publishers. Alexander, P. (2010). Rebellion of the poor: South Africa's service delivery protests. Review of African Political Economy. 37(123), 2540.

ANC see African National Congress.

Clark, D., \& Qizilbash, M. (2005). Core poverty, basic capabilities and vagueness: an application to the South African context. Working paper no 26, Global Poverty Research Group.

Council for Scientific and Industrial Research (CSIR). (2012). Poverty and development. Pretoria.

CSIR see Council for Scientific and Industrial Research.

Crowley, S. (2003). The affordable housing crises: residential mobility of poor families and school mobility of poor children. The Journal of Negro Education. 72(1), 22-38.

De Soto, H. (2000). The mystery of capital. London: Black Swan.

Fjeldstad, O., Geisler, G., Nangulah, S., Nygaard, K., Pomuti, A., Shifotoka, A., \& Van Rooy, G. (2005). Local governance, urban poverty and service dekivery in Namibia. Norway: CMI Reports.

Global Insight. (2012). Global insight regional explorer data base. Johannesburg.

Gumbo, T. (2014). Housing the urban poor in Africa. Pretoria: HSRC.

Harber, A. (2009). The meaning of service delivery. [Online] Available: http://www.theharberbinger.co.za/wordpress (May 15, 2014).

Housing Development Agency. (2012). Free State: Informal settlements status research report. Houghton, Johannesburg.

Mamba, B. (2006). An appraisal of basic infrastructural service delivery and community participation at the local level: a case study of three municipalities in the Eastern Cape. Department of Economics, Rhodes University, Grahamstown. Masters Degree thesis.

Marais, H. (1998). South Africa: Limit to change. Zed Books: London.

Mbeki, T. (2006). State of the nation address 2006 of the president of South Africa, 3 February 2006, Cape Town.

Muller, (2003). Indigent policy: including the poor in the city of Cape Town's income strategy. [Online]. Available: http//www.capetown.gov.za/policies (March 2, 2014).

Nleya, N. (2011). Linking service delivery and protest in South Africa: an exploration of evidence from Khayelitsha. Africanus, 50(1), 313.

Pynoos, J. (1973). Housing urban America. Chicago: Aldine.

Republic of South Africa. 2011. National Development Plan, 2030. The National Planning Commission. Department of the Presidency. Pretoria: Government Printer.

Republic of South Africa. 2014. Housing information. [Online]. Available: http//www.gov.za/aboutsa/housing.htm (May 26, 2014).

SAIRR see South African Institute of Race Relations.

SALGA see South African Local Government Association.

SPII see Studies in Poverty and Inequality Institute.

Sen, A.K. 1999. Development as freedom. New York. University Press.

Shaffer, P. 2008. New thinking on poverty: Implications of globalization poverty reduction strategies. DESA working paper no 65 . United Nations. New York.

Statistics South Africa. (2012a). Subjective poverty in South Africa. Pretoria: Government printer. 
Statistics South Africa. (2012b). Census 2011 municipal fact sheet. Pretoria: Government printer.

Statistic South Africa. (2014). Poverty. [Online]. Available: http://beta2.statssa.gov.za (May 26, 2014).

StatsSA see Statistics South Africa.

Stewart, P. (1997). The reconstruction and development programme 1994-1996. Cape Town: Juta and Co.

Studies in Poverty and Inequality Institute (SPII). 2007. The measurement of poverty in South Africa project: Key issues. Working Paper no 1.Johannesburg.

South African Institute of Race Relations (SAIRR). (2014). Protest action in South Africa: threat, or opportunity for reform. Johannesburg.

South African Local Government Association (SALGA). 2010. Estimating a poverty line: An application to free basic municipal services in South Africa. Johannesburg.

Sundqvist, J. 2009. The role of young people in poverty reduction. The National Council of Swedish Youth Organizations. Stockholm.

Survey data. (2013). Results of a community survey conducted amongst households in the northern Free State region, January 2013 coordinated by D.F. Meyer.

Tomlinson, R. (2007). The development of a low-income housing finance sector in South Africa. Habitat International. 31(1), 77-86.

World Bank. (2003). World development report 2004: making services work for poor people. Washington: World Bank.

Zuma, J. G. (2011). State of the Nation Adress, 2011. [Online]. Available: http//www.info.gov.za/speech (April 12, 2013). 